\title{
A administração pública na tutela coletiva da moralidade administrativa e do patrimônio público: o papel da advocacia pública
}

\author{
Marcelo Rodrigues Mazzei \\ Universidade de Ribeirão Preto (Unaerp) \\ Ribeirão Preto / SP - Brasil \\ Marcelo Tarlá Lorenzi \\ Universidade de Ribeirão Preto (Unaerp) \\ Ribeirão Preto / SP - Brasil \\ Henrique Parisi Pazeto \\ Universidade de Ribeirão Preto (Unaerp) \\ Ribeirão Preto / SP - Brasil \\ Sebastião Sérgio da Silveira \\ Universidade de Ribeirão Preto (Unaerp) \\ Ribeirão Preto / SP - Brasil \\ Zaiden Geraige Neto \\ Universidade de Ribeirão Preto (Unaerp) \\ Ribeirão Preto / SP - Brasil
}

\begin{abstract}
O presente estudo objetiva analisar a atuação da advocacia pública brasileira na defesa coletiva da moralidade administrativa e do patrimônio público. Será abordada superficialmente a estrutura da advocacia pública nacional nas esferas municipal, estadual e federal, com ênfase em seu desenvolvimento institucional até seu paradigma atual. Serão também estudados os maiores problemas existentes para a defesa da moralidade administrativa e do patrimônio público pela advocacia pública, como a falta de autonomia funcional, administrativa e financeira, a interferência política no exercício técnico-formal da carreira e a permanência em alguns advogados públicos da antiga postura funcional baseada na submissão e incúria em face dos problemas postos às suas apreciações. Por fim, serão apontados alguns instrumentos processuais e extraprocessuais disponíveis para a advocacia pública promover a defesa do patrimônio público e o controle da moralidade nos atos administrativos.
\end{abstract}

Palavras-chave: advocacia pública; coletiva; moralidade. 
La administración pública en la protección colectiva de la moralidad administrativa y del patrimonio público: el papel del derecho público

El presente estudio objetiva analizar la actuación del derecho público brasileño en la defensa colectiva de la moralidad administrativa y del patrimonio público. Será abordada superficialmente la estructura del derecho público nacional en la esfera municipal, estatal y federal, con énfasis en su desarrollo institucional hasta su paradigma actual. Además, serán estudiados los más expresivos problemas existentes para la defensa de la moralidad administrativa y del patrimonio público por del derecho público, como la falta de autonomía funcional, administrativa y financiera, la interferencia política en el ejercicio técnico-formal de la carrera y la permanencia en algunos abogados públicos de la antigua postura funcional basada en la sumisión e negligencia frente a los problemas puestos a sus apreciaciones. Por fin, serán apuntados algunos instrumentos procesales y extra-procesales disponibles para el derecho público promover la defensa del patrimonio público y el control de la moralidad en los actos administrativos.

Palabras clave: derecho público; colectivo; moralidad.

The public administration on the collective management of administrative morality and of the public heritage: the role of public advocacy

This study aims to analyze the performance of the Brazilian public advocacy in the collective defense of administrative morality and public heritage. It will be superficially studied the structure of national public advocacy at local, state and federal level, with emphasis on its institutional development to its current paradigm. The major problems for the defense of administrative morality and public property by public law will also be studied, such as the lack of functional, administrative and financial autonomy, political interference in technical and formal exercise of career and the permanence of some public advocates of the old functional framework based on the submission and neglect of the problems presented. Finally, it will be presented some procedural and extra-procedural instruments available for public advocacy to promote the defense of public assets and the control of morality in administrative acts.

Keywords: public advocacy; collective; morality.

\section{Introdução}

Inicialmente, cumpre apontar que a proposta do presente artigo é demonstrar como a advocacia pública pode promover a defesa da moralidade administrativa e do patrimônio público por meio dos instrumentos processuais e extraprocessuais disponíveis, com enfoque principal nos instrumentos de tutela coletiva, demonstrando, ainda, os caminhos para a efetivação da proteção.

A moralidade administrativa está definida constitucionalmente como princípio norteador da administração pública (art. 37, caput, CF), sendo erigida à condição de interesse difuso da sociedade contemporânea. Aliás, para a teoria política, o próprio princípio republicano gera implicitamente o dever de moralidade administrativa (res publica), sendo até mesmo desnecessária sua previsão explícita no texto constitucional. Sua tutela, porém, tem sido pouco efetivada por meio da participação da advocacia pública, circunstância que ocorre por diversos motivos, como pela falta de autonomia institucional ou pela ingerência política direta. Do mesmo modo ocorre com a defesa do patrimônio público. 
A advocacia pública, conforme previsão constitucional (art. 131 da Constituição Federal), fomenta por meio da consultoria jurídica a legítima adoção de políticas públicas, mormente mediante o resguardo da constitucionalidade e legalidade dos atos administrativos. Nesse contexto, a advocacia pública pode atuar como importante instrumento de controle prévio, interno e inibidor da edição de atos administrativos lesivos à moralidade administrativa e ao patrimônio público.

Contudo, a relação entre a advocacia pública e o poder constituído, marcada por frequentes laços de dependência e subserviência, transforma em algumas situações os advogados públicos em meros defensores do administrador público detentor do poder, fugindo dos objetivos constitucionais atribuídos à advocacia pública, mormente quando se trata da defesa da moralidade administrativa e do patrimônio público.

Verifica-se em muitos casos que a tutela em Juízo do patrimônio público depende da vontade política do administrador, estando condicionada à vontade do chefe do Poder Executivo. É como se a defesa do patrimônio público fosse componente de uma política pública facultativa, opcional ao administrador, faculdade esta que não existe. A defesa do patrimônio público é dever de todo servidor público, em especial dos advogados públicos, dotados de legitimidade processual ativa para promoção dessa tutela.

Essa peculiar situação da administração pública brasileira, que é histórica, é bem destacada por Faoro (2012), que aponta nossa comunidade política como patrimonialista e estamental. É patrimonialista porque existe a confusão entre o bem público e o bem particular. É estamental porque é formada por estamentos constituídos por aqueles que detêm o poder. São nichos de poder formados independentemente da classe social ou econômica de seus membros - que necessariamente não pertencem às classes dominantes no sentido marxista -, mas que são componentes de grupos políticos dotados de poder (estamentos), sendo pessoas "servidas de instrumentos políticos derivados de sua posse do aparelhamento estatal" (Faoro, 2012:834).

Bom indicativo da estrutura patrimonialista descrita por Faoro foi o comentário do ministro dos Esportes, Aldo Rebelo, quando indagado sobre os atrasos nas construções dos estádios de futebol para a Copa do Mundo de 2014. Quase que institucionalizando o costume da procrastinação estatal, o ministro comparou a lentidão nas obras com o tradicional atraso de uma noiva: "Nunca fui a um casamento em que a noiva chegasse na hora, mas nunca vi um casamento deixar de acontecer por causa disso. Não há nada que comprometa a realização da Copa" (Fonseca, 2013).

Recorrendo novamente às palavras de Raymundo Faoro, "dessa realidade se projeta, em florescimento natural, a forma de poder, institucionalizada num tipo de domínio: o patrimonialismo, cuja legitimidade assenta no tradicionalismo - assim é porque sempre foi" (Faoro, 2012:819).

Trata-se de uma cultura arraigada no serviço público de total dependência da vontade do administrador eleito, mormente no sentido de optar qual seria a medida mais adequada 
para a tutela coletiva do patrimônio público e da moralidade administrativa. Tem-se um verdadeiro cabresto imaginário quanto à atuação dos advogados públicos na defesa do patrimônio público, inclusive no que tange aos advogados públicos admitidos mediante concurso público e possuidores de estabilidade. Assim, frequentemente o patrimônio público não é considerado patrimônio de todos, mas sim considerado patrimônio de ninguém, livre de qualquer titular.

Para que se possa visualizar a pouca efetividade da atuação judicial da advocacia pública na tutela da moralidade administrativa e do patrimônio público, cabe informar os seguintes dados estatísticos fornecidos pelo serviço de informação ao cidadão do Ministério Público Federal (MPF): somente no ano de 2009, o MPF ajuizou em todo o Brasil 476 ações de improbidade administrativa, tendo ajuizado 456 ações em 2010 e 430 ações em 2011. Já a Procuradoria do Município de Ribeirão Preto, estado de São Paulo, segundo informações obtidas no Pedido Administrativo no 02.2012.028652-8, não ajuizou nenhuma ação de improbidade administrativa nos anos de 2005 a 2012.

Quanto à relevância do estudo da defesa da moralidade e do patrimônio público, uma parcela da população brasileira já deu mostras de insatisfação com as recorrentes notícias de corrupção nos órgãos públicos, inclusive promovendo através de iniciativa popular a criação de leis que tutelam a probidade, como é o caso da Lei Complementar no 135/2010, chamada de "Lei da Ficha Limpa", além do surgimento de diversos movimentos sociais como a "Transparência Brasil" e o "Movimento contra a corrupção".

Assim, justifica-se um estudo específico dos meios de tutela da moralidade pela advocacia pública, que, por representar diretamente o ente público ao qual está ligada (art. 131 e 132 da Constituição Federal e art. 12, incisos I e II do CPC), possui a possibilidade por meio da consultoria jurídica de efetuar o controle prévio na edição de atos administrativos acerca da observância dos princípios constitucionais.

Durante o presente estudo será analisada a atuação da advocacia pública na tutela da moralidade administrativa e do patrimônio público, sendo destacados alguns instrumentos processuais e extraprocessuais disponíveis à advocacia pública. Para a concretização desse desiderato, aponta-se a gradual mudança de paradigma no exercício de suas funções institucionais mediante o rompimento do estigma pautado na descompromissada defesa judicial do ente público e por algumas vezes, infelizmente, do próprio administrador público. Tudo como forma de chegar-se definitivamente a um estágio institucional baseado primordialmente no controle da legalidade dos atos administrativos, independentemente de eventuais vontades políticas dissociadas do interesse público, levantando-se, igualmente, as dificuldades mais frequentes para o livre exercício da advocacia pública no que concerne à defesa da moralidade administrativa e do patrimônio público.

\section{A tutela coletiva da moralidade administrativa e do patrimônio público pela advocacia pública}

A Constituição Federal de 1988 estabeleceu a moralidade administrativa como um dos princípios norteadores da administração pública. Como bem aponta Hely Lopes Meirelles (2004:90), "a moralidade administrativa está intimamente ligada ao conceito do "bom administrador". 
É importante ressaltar que a edição da súmula vinculante no 13 pelo Supremo Tribunal Federal (STF), que trata do nepotismo simples e cruzado, representou um fortalecimento da eficácia do princípio da moralidade, uma vez que restou configurado que os princípios constitucionais não significam meras recomendações de caráter moral ou ético. Mas consubstanciam-se em regras jurídicas de caráter prescritivo, hierarquicamente superiores às demais e positivamente vinculantes, sendo sempre dotadas de eficácia cuja materialização, se necessário, pode ser cobrada por via judicial.

A advocacia pública tem sua previsão constitucional nos arts. 131 e 132, sendo uma das carreiras integrantes do capítulo da Constituição Federal destinado às funções essenciais à Justiça. Para fins de compreensão do presente estudo, apesar de grande divergência doutrinária - fomentada principalmente pela necessidade ou não de inscrição dos integrantes junto à $\mathrm{OAB}$ (Arruda, 2013) —, a Defensoria Pública não será considerada expoente da advocacia pública.

Configura atribuição da advocacia pública a representação judicial e extrajudicial, bem como a consultoria e o assessoramento jurídico dos respectivos entes federativos. A União é representada pela Advocacia-Geral da União (art. 131 da Constituição Federal). Os estados e o Distrito Federal são representados por suas respectivas Procuradorias (art. 132 da Constituição Federal). Os municípios, apesar de inexistência de previsão constitucional expressa do órgão encarregado da sua representação judicial, extrajudicial e consultoria, são representados por suas Procuradorias Municipais ou Secretarias dos Negócios Jurídicos. O art. 12, inciso II, do Código de Processo Civil atribui legitimidade de representação do município ao prefeito ou procurador. Deve-se salientar por oportuno que existe a proposta de Emenda Constitucional no 153/2003, de autoria do deputado federal Maurício Rands, cujo objetivo é incluir os procuradores municipais no rol do art. 132, garantindo a organização da carreira, o ingresso por concurso público daqueles que respondem pela representação judicial e extrajudicial, bem como pelo controle da legalidade dos atos da administração pública municipal.

Conforme elucida Rodolfo de Camargo Mancuso (2003), a atuação do advogado público "se faz próxima aos centros de poder decisório do Estado, de tal sorte que atos, documentos e por vezes até mesmo programas governamentais passam a ter como condição de eficácia a intervenção técnico-formal desses agentes".

Como já apontado, a advocacia pública brasileira vem aos poucos alterando seu paradigma institucional de simples defensora do ente público para efetiva controladora de legalidade dos atos administrativos por ele emanados.

Note-se que poucos estudos até hoje foram realizados especificamente sobre a atuação da advocacia pública brasileira na defesa da moralidade administrativa. Isso se deve principalmente à pouca participação da advocacia estatal na defesa deste interesse difuso. Apesar de a União, os estados, o Distrito Federal e os municípios possuírem legitimidade para o ajuizamento de ação civil pública para a defesa dos interesses difusos e coletivos (art. 5o, inciso III, da Lei oํ 7.347/1985), inclusive para ressarcimento de dano ao erário público e imputação das sanções previstas na lei de improbidade administrativa (art. 17 da Lei no 8.429/1992). Essa ineficácia na utilização dos instrumentos processuais e extraprocessuais disponíveis à 
advocacia pública para defesa da moralidade administrativa decorre de diversos fatores, como a ausência de autonomia administrativa e financeira, a interferência política e a desídia no trato da coisa pública.

Infelizmente, no atual contexto histórico, percebe-se ainda a tentativa por parte de alguns integrantes dos Poderes Executivo e Legislativo de utilizarem a advocacia pública como instrumento jurídico legitimador de atos administrativos ou políticas públicas implantadas sem uma prévia análise técnica-jurídica do órgão consultivo. Mais ainda, permanece a confusão para alguns administradores da utilização da advocacia pública para defesa de interesses privados quando efetuados no exercício do cargo público, mas que, na verdade, são dissociados do interesse público. Como aponta Fábio Medina Osório (1997:96):

A Procuradoria Municipal, a Procuradoria do Estado e a Advocacia da União defendem os interesses dos respectivos Entes Públicos, não se confundindo os interesses da pessoa jurídica com os interesses de seus representantes legais enquanto pessoas físicas. Mais ainda, o sistema constitucional, uma vez calcado na distinção entre pessoas jurídicas de Direito Público e pessoas físicas representantes das primeiras, veda, logicamente, que os interesses pessoais dessas últimas se sobreponham aos interesses dos Entes Públicos.

O Superior Tribunal de Justiça (STJ) possui diversos julgados no sentido de que a defesa particular do agente por procurador público configura improbidade administrativa salvo se houver interesse convergente da administração (Brasil, STJ, AgRg no REsp 798.100RO). Exemplificando, o STJ já decidiu configurar ato de improbidade administrativa a utilização por prefeito municipal da Procuradoria do Município para sua defesa em ação popular ajuizada para declarar a nulidade de atos considerados abusivos no exercício do mandato, como a promoção pessoal irregular em anúncios e obras públicas. Isto mesmo estando também o município no polo passivo da demanda, haja vista que a situação delineada implica benefício pessoal do gestor em detrimento do ente público, configurando conflito de interesses (Brasil, STJ, REsp 1229779/MG).

A pouca atuação da advocacia pública na tutela do patrimônio público e da moralidade administrativa encontra fundamento em diversos fatores, como a falta de autonomia funcional, administrativa e financeira, a interferência política no exercício técnico-formal da carreira e a permanência em alguns advogados públicos da antiga postura funcional baseada na submissão e incúria ante os problemas postos à sua apreciação.

$\mathrm{O}$ antigo perfil atribuído à advocacia pública, contudo, vem aos poucos mudando como se vê, por exemplo, pela formalização de acordo de cooperação técnica entre a AdvocaciaGeral da União (AGU) e o Tribunal Superior Eleitoral (TSE) para que ocorra o repasse de informações entre os órgãos sobre os prefeitos que foram cassados por algum ato ilícito, como forma de possibilitar à AGU cobrar do ex-agente público os valores gastos com os custos de novas eleições. Assim, após o prefeito ser julgado definitivamente, os Tribunais Regionais Eleitorais vão acionar a AGU para que sejam tomadas as providências necessárias para cobrar, por meio das ações judiciais, as despesas geradas pela convocação de nova votação. Fora isso, 
a AGU também pretende formular pedido condenatório a título de dano moral coletivo, haja vista que os delitos cometidos por quem foi cassado causam transtornos aos eleitores, que serão obrigados a votar mais de uma vez em uma única eleição, além de eventuais problemas de gestão ocorridos durante o processo de cassação.

Também vale ressaltar que AGU obteve a condenação por improbidade administrativa em primeira instância do ex-prefeito sergipano de Monte Alegre e de outros três membros da comissão de licitação do município em razão de danos causados aos cofres públicos pelo favorecimento em licitação de empresas denunciadas pela “Operação Sanguessuga”, deflagrada pela Polícia Federal em 2006, que apurou esquema de fraudes na aquisição de ambulâncias. (Ação Civil Pública no 0000274-15.2008.4.05.8501)

Ciente das particularidades vivenciadas pela advocacia pública, existe a proposta de Emenda Constitucional (PEC no 82/2007), de autoria do deputado federal Flávio Dino, que visa acrescentar à Constituição Federal, dentre outros, o art. 132-A, o qual assegura as autonomias funcional, administrativa e financeira, assim como o poder de iniciativa de suas políticas remuneratórias e das propostas orçamentárias anuais. Em sua justificativa, o parlamentar afirma que a sistemática da Constituição da República prega o paralelismo de atributos entre as instituições públicas de Estado, sobretudo entre aquelas consideradas essenciais à realização do bem comum.

Vale lembrar que o STF, no julgamento da ADI no 217/PB (STF, 2002), julgou inconstitucional o art. 135, inciso I, da Constituição Estadual da Paraíba, que atribuía autonomia funcional, administrativa e financeira à Procuradoria do Estado, sob o fundamento de que desvirtuava a configuração jurídica fixada pelo texto constitucional à advocacia pública, desrespeitando o art. 132 da Carta Magna.

\section{Instrumentos de tutela processual e procedimentos de defesa extraprocessuais disponíveis à advocacia pública para defesa da moralidade administrativa e do patrimônio público}

Entre os diversos instrumentos processuais disponíveis à advocacia pública para promover a defesa do patrimônio público e da moralidade administrativa, tem-se destaque para a legitimidade de ajuizamento de ação de improbidade administrativa, inclusive com pedido de indisponibilidade de bens dos envolvidos (art. 7o da Lei no 8.429/1992), além da faculdade da assunção do polo ativo na ação popular (art. 6º, § 3ํ da Lei no 4.717/1965).

O art. 17 da Lei no 8.429/1992 estabelece a legitimidade ativa do Ministério Público e da pessoa jurídica interessada para a propositura da ação de improbidade administrativa. Assim, o ente federativo lesado pelo ato de improbidade detém legitimidade para o ajuizamento da ação de improbidade por meio dos advogados públicos que lhe representam. Igualmente, o $\S 2^{\circ}$ do mencionado artigo prevê que a Fazenda Pública, quando for o caso, promoverá as ações necessárias à complementação do ressarcimento do patrimônio público. 
Igualmente, o art. 19 da Lei $\mathrm{n}^{\mathrm{o}}$ 12.846/2013, que trata da responsabilização administrativa e civil de pessoas jurídicas pela prática de atos contra a administração pública, nacional ou estrangeira, estabelece a legitimidade da advocacia pública do ente prejudicado para propor ação judicial que seguirá o rito da ação civil pública (art. 21 da Lei no 12.846/2013) para fins de aplicação das seguintes penalidades às pessoas jurídicas infratoras: perdimento dos bens, direitos ou valores que representem vantagem ou proveito direta ou indiretamente obtidos da infração; suspensão ou interdição parcial das atividades da pessoa jurídica; dissolução compulsória da pessoa jurídica e proibição de receber incentivos, subsídios, subvenções, doações ou empréstimos de órgãos ou entidades públicas e de instituições financeiras públicas ou controladas pelo poder público, pelo prazo mínimo de 1 (um) e máximo de 5 (cinco) anos.

Em resposta ao pedido no 5807 , o serviço de atendimento ao cidadão da PGE/RS informou que a Procuradoria Geral do Estado do Rio Grande do Sul, por meio de sua Procuradoria Disciplinar e de Probidade Administrativa, ajuizou 62 ações de improbidade administrativa no período de 2009 a 2012.

A indisponibilidade do erário público e o receio do protecionismo e da incúria dos membros do poder público fundamentaram o teor da redação do art. 7o, § 1ํㅡㄹ da Lei no 8.429/1992, que veda a transação, acordo ou conciliação nas ações de improbidade administrativa.

O art. 7ํ da Lei no 8.429/1992 prevê a possiblidade do pedido de indisponibilidade de bens dos envolvidos nos atos de improbidade. Pela leitura apressada do artigo, pode-se surgir uma ideia equivocada de que somente o Ministério Público seria legitimado para o pedido de indisponiblidade. A melhor exegese, contudo, é a de que qualquer legitimado para a propositura da ação de improbidade é legitimado para o pedido de indisponibilidade, justamente em razão de sua natureza cautelar e preventiva, que objetiva assegurar o efeito prático relativo ao ressarcimento do erário público no caso de futura eventual condenação dos envolvidos, assumindo, assim, natureza parecida com o arresto de bens (Decomani, 2007:275). Igualmente, em virtude de sua natureza cautelar, o pedido de indisponibilidade pode ser feito em ação preparatória (Brasil, STJ, AgRg no REsp 1317653/SP) ${ }^{1}$ ou incidentalmente na ação civil pública. É admissível a concessão de liminar sem a oitiva da parte contrária (inaudita altera pars) para a decretação de indisponibilidade ou sequestro de bens dos réus.

Deve-se ressaltar, pela importância, que o STJ possui recente julgado no sentido de admitir o pedido de indisponibilidade de bens feito em sede de ação popular, baseado, entretanto, no poder geral de cautela do magistrado e sem alusão explícita ao art. 7o da Lei de Improbidade. No acórdão, ficou assentado que, inexistindo qualquer impedimento ou incompatibilidade flagrante com a Lei no 4.717/1965, é plenamente cabível, em tese, com base no art. 22 do referido diploma, a postulação de tutelas urgentes, de natureza cautelar nominada ou inominada, previstas nos arts. 798, 799 e seguintes do Código de Processo Civil, tal como a

\footnotetext{
${ }^{1}$ A jurisprudência desta Corte Superior de Justiça é no sentido de que a decretação da indisponibilidade e do sequestro de bens em ação de improbidade administrativa é possível antes do recebimento da Ação Civil Pública.
} 
indisponibilidade de bens para garantir o ressarcimento do erário, um dos principais objetivos da ação popular (art. 11 da Lei no 4.717/1965) (Brasil, STJ, AgRg no REsp 957.878/MG).

$\mathrm{O}$ pedido de indisponibilidade de bens tem cabimento perante quaisquer atos de improbidade administrativa, inclusive aqueles que impliquem violação dos princípios da administração pública, mormente para assegurar o integral ressarcimento de eventual prejuízo ao erário, e ainda a multa civil prevista no art. 12, inciso III da Lei no 8.429/1992 como sanção autônoma (Brasil, STJ, AgRg no REsp 1311013/RO). Segundo decisões do STJ, a medida de indisponibilidade patrimonial aplicada aos réus não deve se restringir apenas a um eventual enriquecimento ilícito, mas deve garantir a reparação de todas as consequências financeiras decorrentes dos atos ímprobos (Brasil, STJ, EDcl no REsp 1314092/PA).

Na petição inicial não é necessária a individualização dos bens que sofrerão os efeitos da indisponibilidade (Brasil, STJ, AgRg no REsp 1282253/PI). A indisponibilidade de bens representa uma tutela de evidência (Bedaque, 2006:339), ${ }^{2}$ já que sua decretação não está condicionada à comprovação de dilapidação efetiva ou iminente de patrimônio do réu, porquanto visa, justamente, a evitar dilapidação patrimonial (BRASIL, STJ, REsp 1280826/MT). O periculum in mora é presumido, já que está implícito no comando legal do pedido de indisponibilidade (Brasil, STJ, REsp 1319583/MT), uma vez que ele não é oriundo da intenção do agente dilapidar seu patrimônio, mas sim da gravidade dos fatos e do montante do prejuízo causado ao erário, que atinge toda a coletividade (Brasil, STJ, REsp 1.319.515/ES).

Como visto, segundo a posição majoritária do STJ, a indisponibilidade dos bens é cabível quando o julgador entender presentes fortes indícios de responsabilidade na prática de ato de improbidade que cause dano ao erário, estando o periculum in mora implícito no referido dispositivo, atendendo determinação contida no art. 37, §4º da Constituição Federal (Brasil, STJ, AgRg nos EREsp 1315092/RJ).

O pedido de indisponibilidade de bens nos casos de ação de improbidade administrativa poderá compreender o patrimônio de todos os réus, uma vez que a responsabilidade é solidária até a instrução final do feito, onde aí então se delimitará a quota de responsabilidade de cada agente para a dosimetria da pena (Brasil, STJ, AgRg no REsp 951.528/PR).

Apesar de julgados sustentarem que a Lei ํㅗ 8.429/1992 não pode ser aplicada retroativamente para alcançar bens adquiridos antes de sua vigência, devendo a indisponibilidade dos bens atingir somente os bens adquiridos após o ato tido como ímprobo (Brasil, STJ, REsp 196.932/SP), o STJ possui atual entendimento no sentido de que os preceitos da Lei no ${ }^{\circ} .429 / 1992$ podem ser aplicados a fatos ocorridos antes de sua vigência, podendo a indisponibilidade dos bens recair sobre tantos bens quantos forem necessários ao ressarcimento do dano, mesmo aqueles adquiridos antes ou depois do ato de improbidade administrativa

\footnotetext{
2 "A tutela diferenciada funda-se ora na urgência na entrega da prestação jurisdicional, ora na evidência de que o direito afirmado existe. Teríamos, pois, como espécies de tutela diferenciada, a tutela de urgência e a de evidência (...) A tutela diferenciada, portanto, pode estar vinculada ao valor urgência, ao valor evidência ou a ambos (...) Tendo em vista características da situação, fica dispensado o risco concreto de dano. Busca-se afastar o mal causado pela demora do processo, por si mesmo fator de risco para a utilidade do resultado."
} 
(Brasil, STJ, REsp 401.437/SP). Por fim, note-se que o caráter de bem de família do imóvel do réu não tem a força de obstar a determinação de sua indisponibilidade nos autos de ação civil pública de improbidade administrativa, pois tal medida não implica expropriação do bem (Brasil, STJ, REsp 1204794/SP).

A utilização do pedido de indisponibilidade de bens pela advocacia pública para defesa do patrimônio público pode ser verificada em alguns exemplos existentes. No processo oㅡ 20103200000800-4, que tramita na 1a - Vara Federal de Manaus (AM), a Procuradoria Federal no estado do Amazonas conseguiu liminar que determinou o bloqueio e a indisponibilidade de aproximadamente R $\$ 155$ mil em bens da prefeita Eliete da Cunha Beleza da cidade de Santa Isabel do Rio Negro, no Amazonas. O valor corresponde à verba repassada ao município pelo Fundo Nacional de Desenvolvimento da Educação (FNDE) e que não foi usado nos projetos aos quais se destinavam, durante a primeira gestão da prefeita (AGU, 2013).

A Procuradoria Federal no Estado do Tocantins (PF/TO) e a Procuradoria Federal junto ao Fundo Nacional de Desenvolvimento da Educação (PF/FNDE) obtiveram decisão favorável na Ação Civil Pública ํo 8115-26.2012.4.01.4300, em trâmite pela 2 ${ }^{\text {a }}$ Vara da Seção Judiciária do Tocantins, como forma de assegurar a indisponibilidade de bens e valores do ex-prefeito do município de Rio Sono (TO), visando resguardar futuro ressarcimento ao erário por ato de improbidade administrativa. O ex-prefeito é acusado de receber em 2009 recursos do Programa Nacional de Apoio ao Transporte Escolar sem a devida comprovação da boa aplicação dos recursos, com o descumprimento do dever legal de prestar contas, o que ocasionou perante o Tribunal de Contas da União (TCU) a instauração de uma tomada de contas especial, onde se apurou um prejuízo de mais de $\mathrm{R} \$ 48$ mil aos cofres públicos.

Note-se, por oportuno, que a recente Lei nํㅜ 12.846/2013 também prevê a possibilidade do pedido de indisponibilidade de bens nas ações ajuizadas em face de pessoas jurídicas com base em sua responsabilização civil ou administrativa ${ }^{3}$ (art. 19, §4ํ).

Importante destacar, por oportuno, que o art. 17, §3으, da Lei ํㅛ 8.429/1992, com a redação dada pela Lei $n^{\circ} 9.366 / 1996$, determina que, no caso de a ação principal ter sido proposta pelo Ministério Público, o magistrado deverá agir conforme o disposto no art. 6º, §3ํㅡㄴ da Lei da Ação Popular (4.717/1965). Segundo esse parágrafo, a pessoa jurídica de direito público ou de direito privado, cujo ato seja objeto de impugnação na ação popular, poderá abster-se de contestar o pedido, ou poderá atuar ao lado do autor, desde que isso se afigure útil ao interesse público, a juízo do respectivo representante legal ou dirigente.

Note-se que a redação primitiva do §3ํㅡㄹ do art. 17 da Lei no 8.429/1992, antes de sua alteração pela Lei nº 9.366/1996, previa nas hipóteses de a ação ter sido proposta pelo Ministério Público a intevenção da pessoa jurídica interessada na lide na qualidade de litisconsorte,

\footnotetext{
${ }^{3} \S 4$ o 0 Ministério Público ou a Advocacia Pública ou órgão de representação judicial, ou equivalente, do ente público poderá requerer a indisponibilidade de bens, direitos ou valores necessários à garantia do pagamento da multa ou da reparação integral do dano causado, conforme previsto no art. 7ํ, ressalvado o direito do terceiro de boa-fé.
} 
como forma de possibilitar a correção de eventuais omissões e falhas da petição inicial, bem como para possibilitar a apresentação ou indicação de meios de prova que achar pertinente.

A leitura do art. 17, §3ํㅡㄹ da Lei no 8.429/1992 gerou em parte da doutrina a interpretação no sentido da obrigatoriedade da citação da pessoa jurídica interessada quando o ajuizamento da ação de improbidade administativa tiver sido feito pelo Ministério Público. O STJ, no julgamento do AgRg nos EREsp 329.735/RO, min. Castro Meira, DJ de 14/6/2004, assentou o entendimento de que a falta de citação da pessoa jurídica de direito público interessada não acarreta a nulidade do processo, por se tratar de litisconsorte facultativo.

A melhor exegese da norma, contudo, aponta no sentido da inexistência de nulidade pela ausência de citação da pessoa jurídica interessada, haja vista não se tratar de litisconsórcio necessário (art. 47 do CPC), mas simples litisconsórcio facultativo, devendo, em qualquer caso, ser demonstrado o efetivo prejuízo para possível reconhecimento de nulidade. Desse modo, a norma não determina a citação obrigatória da pessoa jurídica de direito público interessada sob pena de nulidade absoluta, mas lhe faculta contestar o pedido (polo passivo), abster-se de contestar ou atuar junto ao autor no polo ativo da demanda (TJSP — Apelação com revisão no 0096248-63.2002.8.26.0000). Evidencia-se, assim, não se tratar de hipótese de litisconsórcio necessário, por ser facultativa, a critério da pessoa jurídica de direto público, sua intervenção no processo, conforme voto do ministro Teori Albino Zavaski (BRASIL, STJ, REsp 565.317/RO). Igualmente, a natureza da relação jurídica em questão não induz, obrigatoriamente, a um litisconsórcio necessário (Pazzaglini Filho, 2005:205). ${ }^{4}$

O STJ possui entendimento sedimentado no sentido de que na ação civil pública por ato de improbidade, quando o autor é o Ministério Público, a pessoa jurídica de direito público interessada sustenta a qualidade de litisconsorte facultativa e não litisconsorte necessário (Brasil, STJ, REsp 889.534/MG). Com isso, não constitui nulidade processual constatável de plano a não intervenção do ente público interessado na ação de improbidade (BRASIL, STJ, REsp 565.317/RO), já que incide, no caso, a regra oriunda do princípio da instrumentalidade das formas, no sentido de que não há nulidade sem demonstração do efetivo prejuízo pela parte (art. 244, do CPC).

Interessante destacar que o STJ já teve a oportunidade de julgar um recurso que abordava a necessidade ou não de intimação da pessoa jurídica interessada quando a ação de improbidade tivesse sido proposta por outro legitimado que não o Ministério Público (Brasil, STJ, REsp 1263538/BA). Tratava-se o caso de uma ação civil pública proposta pela União visando à apuração de fatos relativos a fraudes em processos licitatórios da Universidade Federal do Estado da Bahia (Ufba). O STJ entendeu que a melhor exegese do art. 17, §3º, da Lei no 8.249/1992 é a que admite a intimação da pessoa jurídica quando a ação for proposta por órgão diverso dela própria. Assim, deu provimento ao recurso interposto para que se

\footnotetext{
4 "De se ver, ainda, que a ausência de citação da pessoa jurídica de direito público, suposta vítima da atuação funcional do agente público contra o qual o Ministério Público propõe ação civil de improbidade administrativa, não implica em nulidade processual, pois, na espécie, trata-se de litisconsórcio facultativo.”
} 
realizasse a intimação da Ufba para lhe facultar as prerrogativas previstas no §3을 do art. $6^{\circ}$ da Lei 4.717/1965.

Também é possível à Fazenda Pública a assunção do polo ativo em ação popular quan-

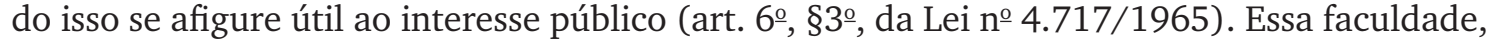
contudo, não é muito utilizada, especialmente no âmbito estadual e municipal. Isso ocorre porque na maioria dos casos o ato impugnado foi feito na gestão do atual representante político. Por pressões políticas, a análise do interesse público fica relegada a segundo plano, o que dá azo sempre à defesa do ato impugnado. O fato político também pode estar presente no sentido inverso. A assunção do polo ativo pela Fazenda Pública lesada pode ser motivada por um viés eleitoreiro, em especial nas situações em que o ato impugnado possa afetar de algum modo aos adversários políticos do atual administrador do ente federativo.

Para melhor visualização da problemática, segundo informações fornecidas pelo pedido administrativo no 02.2012.028652-8, a Procuradoria Geral do Município de Ribeirão Preto (SP), no período de 2005 a 2012, não assumiu, como lhe faculta o art. 6으, §3ํㅡ, da Lei no 4.717/65, o polo ativo nas ações populares ajuizadas em face da Prefeitura, sempre optando pela defesa do ato impugnado, promovendo 58 defesas no período mencionado.

Em se tratando de ação popular, é permitido ao ente público migrar do polo passivo para o ativo a qualquer tempo, mesmo após a apresentação de contestação, ocorrendo a migração a juízo de seu representante legal com a finalidade de defender o interesse público (Brasil, STJ, REsp 1185928/SP). Não há que se falar assim em preclusão lógica pela apresentação da contestação, pois, além de a mencionada lei não trazer limitação quanto ao momento em que deve ser realizada a migração, o seu art. 17 preceitua que a entidade pode, ainda que tenha contestado a ação, proceder à execução da sentença na parte que lhe caiba, ficando evidente a viabilidade de composição do polo ativo a qualquer tempo (Brasil, STJ, REsp 945238/SP).

Como visto, é aceita majoritariamente pelo STJ a tese da retratabilidade do ente público, quando este, apesar de ter oferecido contestação ao pedido da ação popular, convence-se da ilegalidade e lesividade do ato, inexistindo óbice para que o ente público assuma o polo ativo da demanda em nome do interesse público (Brasil, STJ, AgRg no REsp 439854/MS). Igualmente, o fato de o ente público ter pedido prazo em dobro para responder à ação não quer dizer que ele praticou ato incompatível com a faculdade de requerer o ingresso no polo ativo da relação processual (Brasil, STJ, AgRg no REsp 973905/SP).

Ademais, a advocacia pública poderá habilitar-se, em nome do poder público, como litisconsorte do Ministério Público ou de qualquer outro legitimado para a propositura de ação civil pública, nos termos do art. 5ํ, §2 da Lei no 7.347/1985. Caberá inclusive o instituto da assistência, conforme determinação de aplicação dos dispositivos da Lei de Ação Popular, em observância ao art. 1ํ da Lei 7.347/1985 e art. 6º, §5º da Lei no 4.717/1965; concluiu-se que ambas as ações estariam relacionadas, o que admitiria o uso da analogia entre elas (Vicentin, 2011:663).

Assim, constata-se que a advocacia pública pode atuar em conjunto com o Ministério Público, e com os demais legitimados, para fortalecer e enriquecer o processo da ação civil pública visando à defesa do patrimônio público lesado; não obstante poder atuar também in- 
dividualmente, conforme disposição do art. 5 da Lei de Ação Civil Pública. Para esse fortalecimento seria importante que houvesse um estreitamento no relacionamento entre os membros da advocacia pública e do Ministério Público, através do encaminhamento de informações relevantes por parte do advogado público que possam embasar o ingresso da ação, no caso de algum empecilho político dificultar o ingresso da ação diretamente pelo ente legitimado; tudo para atingir o primado da legalidade e moralidade no trato da coisa pública.

Essa cooperação restaria necessária até que as Advocacias Públicas, ou mais precisamente as Procuradorias dos municípios, estados e da União, atingissem a necessária e esperada autonomia e independência para defender o patrimônio público, dentro dos limites da Constituição e das leis pertinentes; que poderá vir com a aprovação da já mencionada Proposta de Emenda Constitucional no 82-A/2007, prevista para votação no plenário da Câmara dos Deputados no ano de 2014, visando alterar o art. 132 da Constituição Federal.

Nesse sentido, Moreira Neto já dizia há tempos que um dos princípios constitucionais da procuratura pública é a independência funcional e as autonomias administrativas e de impulso (Moreira Neto, 1992:92).

Quanto aos instrumentos extraprocessuais disponíveis à advocacia pública para defesa do patrimônio público e da moralidade administrativa, podemos destacar a função consultiva como de extrema relevância para o controle prévio dos atos administrativos.

De grande relevo para fins de controle da legalidade dos atos administrativos o exercício da consultoria jurídica interna por parte dos advogados públicos, inclusive com a possiblidade da criação de súmulas administrativas com o escopo de pacificar entendimentos da administração pública, desburocratizando, assim, procedimentos que costumam demandar muito tempo. Igualmente, mostra-se importante a presença dos advogados públicos na qualidade de técnicos no que pertine à elaboração de minutas de leis e na expedição de recomendações de condutas aos demais servidores públicos. A participação consultiva no processo administrativo disciplinar também resulta importante, principalmente no que tange ao controle da legalidade dos atos apuratórios, mormente para assegurar a garantia da concessão da ampla defesa e contraditório ao investigado.

A importância da função consultiva da advocacia pública para o controle da legalidade

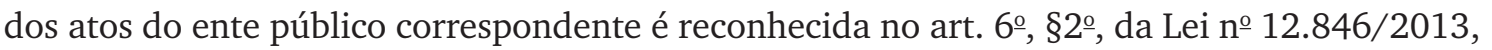
que prevê a obrigatoriedade da elaboração de manifestação jurídica prévia pela Advocacia Pública ou pelo órgão de assistência jurídica do ente público para fins de aplicação das sanções administrativas previstas na lei.

Importante destacar que o STF já teve a oportunidade de decidir sobre a extensão da responsabilidade do advogado público na elaboração de pareceres técnicos no julgamento do Mandado de Segurança no 24.631/DF (STF, 2007), em que ficou assentado que, salvo demonstração de culpa ou erro grosseiro, submetida às instâncias administrativo-disciplinares ou jurisdicionais próprias, não cabe a responsabilização do advogado público pelo conteúdo de seu parecer de natureza meramente opinativa. Isso ocorre "porque quem pratica o ato é o administrador, e não o advogado que apenas dá sua opinião acerca da melhor conduta a ser tomada naquele caso" (Pinheiro de Amorim, 2008:261), possuindo o parecer, então, natureza 
de opinião técnica-jurídica e não de ato administrativo propriamente dito. $\mathrm{O}$ ato administrativo em si, no caso, consubstancia-se no ato de acolhimento ou rejeição do parecer pela autoridade administrativa competente.

Os advogados públicos também poderão celebrar termos de ajustamento de conduta (TAC) em nome da pessoa jurídica de direito público representada, como forma de prevenir condutas de servidores ou particulares que de alguma forma vulnerem a moralidade administrativa ou impliquem lesão ao patrimônio público. Quanto aos legitimados para celebração de termo de ajustamento de conduta, Hugo Nigro Mazzilli aponta a legitimidade dos órgãos públicos, independentemente da personalidade jurídica (BRASIL, STJ, REsp 1194767/SP)5, mas desde que destinados para a proteção de interesses coletivos lato sensu e individuais homogêneos:

Segundo o sistema vigente, só podem tomar o compromisso de ajustamento de conduta os órgãos públicos legitimados à ação civil pública ou coletiva. (...) Examinando-se o rol dos legitimados ativos, constante do art. 5ㅇ da LACP e do art. 82 do CDC, podemos relacionar três categorias: a daqueles legitimados que, incontroversamente podem tomar compromisso de ajutsamento: Ministério Público, União, Estados, Municípios, Distrito Federal e órgãos públicos, ainda que sem personalidade jurídica, especificamene destinados à defesa de interesses difusos, coletivos e individuais homogêneos. (Mazzilli, 2010:418)

Note-se que o termo de ajustamento de conduta (TAC) é título executivo extrajudicial, que permite seu cumprimento judicialmente. A ele poderá ser imposta multa por descumprimento, bem como poderão constar outras sanções administrativas ou cíveis condizentes com a gravidade da conduta irregular a ser cessada.

O art. 4 da Lei no 9.469/1997 prevê a legitimidade da AGU em firmar termo de ajustamento de conduta para prevenir ou terminar litígios, nas hipóteses que envolvam interesse público da União, suas autarquias e fundações. A AGU poderá solicitar aos órgãos e entidades públicas federais manifestação sobre a viabilidade técnica, operacional e financeira das obrigações a serem assumidas em termo de ajustamento de conduta, cabendo ao advogado-geral da União a decisão final quanto à sua celebração (parágrafo único do art. 4ํ da Lei no 9.469/97).

A função consultiva na análise de editais de licitação também se mostra de extrema relevância para a verificação de eventuais irregularidades que ocasionem prejuízos ao patrimônio público ou que, de qualquer forma, representem desvio da finalidade pública que caracterize ofensa à moralidade administrativa. Em artigo científico sobre o tema, Angélica Moreira Dresch da Silveira aborda as formas mais rotineiras de burla pelos agentes públicos das rígidas normas prevista na Lei no 8.666/1993, como o direcionamento da licitação, su-

\footnotetext{
${ }^{5}$ É o exemplo do Procon na defesa dos interesses do consumidor.
} 
perfaturamento de preços e o fracionamento de despesa, demonstrando ao longo do estudo a importância da atividade consultiva da AGU desenvolvida pelos Núcleos de Assessoramento Jurídico nos Estados na prevenção da corrupção, que fomentam a preservação da probidade dentro dos procedimentos licitatórios e de contratações diretas:

O assessoramento jurídico aos órgãos da Administração Pública, no controle interno da legalidade administrativa dos atos a serem por eles praticados ou já efetivados, e em especial, o exame das regras que disciplinarão o procedimento licitatório, bem como daquelas que deverão regular a execução contratual, e dos atos pelos quais se vá reconhecer a inexigibilidade ou decidir a dispensa de licitação, constituem funções específicas dos Núcleos de Assessoramento Jurídico (NAJs), unidades da Consultoria-Geral da União (CGU), órgão de direção superior da Advocacia-Geral da União (AGU). (...) A análise preventiva, realizada pelos núcleos de assessoramento da AGU, comporta ainda a advertência de que, mesmo após publicado o edital ou expedido o convite, sendo constatado que o valor estimado atribuído ao objeto da licitação não condiz com os preços praticados no mercado (porque possivelmente superfaturados), deve o ordenador de despesas declarar a nulidade parcial do procedimento licitatório, alcançando todos os atos praticados desde a aprovação da estimativa de custos baseada em pesquisa de preços superfaturada ou deficientemente instruída, determinando prazo para que outra pesquisa de preços seja elaborada; sob pena de responder solidariamente pela recomposição dos prejuízos advindos da contratação efetivada com preços abusivos. (Dresch da Silveira, 2009)

Por fim, outra atividade útil e possível de ser realizada pelos advogados públicos é o envio de projetos técnicos ao Fundo de Defesa dos Direitos Difusos (art. 13 da Lei no 7.347/1985) para obtenção de recursos financeiros para aplicação em políticas públicas educacionais de combate à corrupção no âmbito do ente federativo representado. No estado de São Paulo é permitido o envio de projetos por parte da administração pública de todas as esferas (federal, estadual e municipal), bem como por parte da sociedade civil (art. 8o da Lei Estadual $n^{\circ}$ 6.536/1989 com redação dada pela Lei Estadual no 13.555/2009 e art. 8o do Decreto Estadual no 27.070/1987). O recebimento das propostas é feito através de edital de abertura específico publicado pelo Conselho Gestor do Fundo Estadual de Defesa dos Interesses Difusos (art. 1o, incisos III e VI do Regimento Interno do Conselho Gestor do FID).

\section{Conclusão}

Como demonstrado no decorrer do presente estudo, no que tange à defesa da moralidade administrativa e do patrimônio público, o atual contexto da advocacia pública é de evolução. Evolução esta que decorre de uma mudança gradativa no paradigma institucional da advocacia pública, de simples defensora do ente público para uma efetiva controladora da legalidade 
dos atos administrativos. E essa mudança parte da iniciativa do advogado público, que deveria abstrair as vontades políticas, tendo como facilitador o respaldo do fortalecimento legal da sua autonomia e independência, necessárias para a defesa do patrimônio público.

Apesar das inúmeras vicissitudes enfrentadas pelos advogados públicos para o desenvolvimento de uma rede de proteção do patrimônio público isenta de influências políticas, tem-se que a advocacia pública surge como mais uma instituição voltada para a defesa da moralidade administrativa.

Essa defesa é proporcionada pelo exercício dos instrumentos processuais e extraprocessuais disponíveis no ordenamento jurídico à advocacia pública para a efetiva proteção da moralidade administrativa e do patrimônio público.

Entre os instrumentos processuais pode-se destacar a legitimidade ativa para o ajuizamento de ação de improbidade administrativa, inclusive com pedido de indisponibilidade de bens dos envolvidos (art. 7ㅇ da Lei no 8.429/1992), bem como a possibilidade de usufruir da faculdade da assunção do polo ativo na ação popular quando isso for benéfico ao interesse

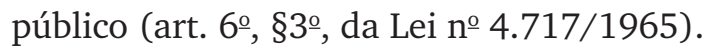

Quanto aos instrumentos extraprocessuais, pode-se apontar a consultoria jurídica interna para controle da legalidade dos atos administrativos, a expedição de recomendações de condutas aos servidores públicos quanto ao exercício da função, a criação de súmulas administrativas para uniformização de procedimentos, a celebração de termos de ajustamento de conduta, bem como a elaboração de projetos técnicos para encaminhamento ao Fundo de Defesa dos Direitos Difusos (art. 13 da Lei no 7.347/1985) com o intuito de obter recursos financeiros para aplicação em políticas públicas educacionais voltadas ao combate à corrupção e para a conservação do patrimônio público no âmbito do ente federativo representado.

\section{Referências}

ADVOCACIA-GERAL DA UNIÃO. Banco de dados. Disponível em: <www.agu.gov.br/sistemas/site/ TemplateTexto.aspx $?$ idConteudo $=152001 \&$ orden acao $=0 \& i d$ site $=782>$. Acesso em: 26 ago 2013 .

ARRUDA, Ígor A. Defensor público não exerce advocacia pública. Jus Navigandi, Teresina, v. 18, n. 3486, 16 jan. 2013. Disponível em: < http://jus.com.br/artigos/23468> . Acesso em: 30 ago. 2013.

BEDAQUE, José Roberto dos S. Tutela cautelar e tutela antecipada: tutelas sumárias e de urgência. 4. ed. São Paulo: Malheiros, 2006.

BRASIL. Superior Tribunal de Justiça. AgRg no REsp 798.100RO, rel. ministro Castro Meira, Segunda Turma, julgado em 27/10/2009, DJe, 9 nov. 2009.

BRASIL. Superior Tribunal de Justiça. REsp 1.229.779/MG, rel. ministro Herman Benjamin, Segunda Turma, julgado em 16/8/2011, DJe, 5 set. 2011.

BRASIL. Superior Tribunal de Justiça. AgRg no REsp 1.317.653/SP, rel. ministro Mauro Campbell Marques, Segunda Turma, julgado em 7/3/2013, DJe, 13 mar. 2013. 
BRASIL. Superior Tribunal de Justiça. AgRg no REsp 957.878/MG, rel. ministro Castro Meira, Segunda Turma, julgado em 11/12/2012, DJe, 4 fev. 2013.

BRASIL. Superior Tribunal de Justiça. AgRg no REsp 1.311.013/RO, rel. ministro Humberto Martins, Segunda Turma, julgado em 4/12/2012, DJe, 13 dez. 2012.

BRASIL. Superior Tribunal de Justiça. EDcl no REsp 1314092/PA, rel. ministra Eliana Calmon, Segunda Turma, julgado em 28/5/2013, DJe, 13 jun. 2013.

BRASIL. Superior Tribunal de Justiça. AgRg no REsp 1282253/PI, rel. ministro Castro Meira, Segunda Turma, julgado em 26/2/2013, DJe, 5 mar. 2013.

BRASIL. Superior Tribunal de Justiça. STJ, REsp 1280826/MT, rel. ministro Herman Benjamin, Segunda Turma, julgado em 11/12/2012, DJe, 19 dez. 2012.

BRASIL. Superior Tribunal de Justiça. REsp 1319583/MT, rel. ministra Eliana Calmon, Segunda Turma, julgado em 13/8/2013, DJe, 20 ago. 2013.

BRASIL. Superior Tribunal de Justiça. REsp 1.319.515/ES, rel. ministro Napoleão Nunes Maia Filho, Rel. p/ acórdão min. Mauro Campbell Marques, DJe, 21 set. 2012.

BRASIL. Superior Tribunal de Justiça. AgRg nos EREsp 1315092/RJ, rel. ministro Mauro Campbell Marques, Primeira Seção, julgado em 22/5/2013, DJe, 7 jun. 2013.

BRASIL. Superior Tribunal de Justiça. AgRg no REsp 951.528/PR, rel. ministro Humberto Martins, Segunda Turma, julgado em 3/3/2009, DJe, 31 mar. 2009.

BRASIL. Superior Tribunal de Justiça. REsp 196.932/SP, rel. ministro Garcia Vieira, Primeira Turma, julgado em 18/3/1999, DJ, 10 maio 1999, p. 119.

BRASIL. Superior Tribunal de Justiça. REsp 401.437/SP, rel. ministro João Otávio de Noronha, Segunda Turma, julgado em 16/10/2007, DJ, 9 nov. 2007, p. 235.

BRASIL. Superior Tribunal de Justiça. REsp 1204794/SP, rel. ministra Eliana Calmon, Segunda Turma, julgado em 16/5/2013, DJe, 24 maio 2013.

BRASIL. Superior Tribunal de Justiça. REsp 565.317/RO, rel. ministro Luiz Fux, primeira turma, julgado em 14/9/2004, DJ, 5 dez. 2005, p. 223.

BRASIL. Superior Tribunal de Justiça. REsp 889.534/MG, rel. ministra Eliana Calmon, Segunda Turma, julgado em 4/6/2009, DJe, 23 jun. 2009.

BRASIL. Superior Tribunal de Justiça. REsp 565.317/RO, rel. ministro Luiz Fux, primeira turma, julgado em 14/9/2004, DJ, 5 dez. 2005, p. 223.

BRASIL. Superior Tribunal de Justiça. REsp 1263538/BA, rel. ministro Herman Benjamin, Segunda Turma, julgado em 16/2/2012, DJe, 7 mar. 2012.

BRASIL. Superior Tribunal de Justiça. REsp 1185928/SP, rel. ministro Castro Meira, Segunda Turma, julgado em 15/6/2010, DJe, 28 jun. 2010.

BRASIL. Superior Tribunal de Justiça. STJ, REsp 945238/SP, rel. ministro Herman Benjamin, Segunda Turma, julgado em 9/12/2008, DJe, 20 abr. 2009. 
BRASIL. Superior Tribunal de Justiça. AgRg no REsp 439854/MS, rel. ministra Eliana Calmon, Segunda Turma, julgado em 8/4/2003, DJ, 18 ago. 2003, p. 194.

BRASIL. Superior Tribunal de Justiça. AgRg no REsp 973905/SP, rel. ministro Humberto Martins, Segunda Turma, julgado em 4/6/2009, DJe, 25 jun. 2009.

BRASIL. Superior Tribunal de Justiça. REsp 1194767/SP, rel. ministro Mauro Campbell Marques, Segunda Turma, julgado em 14/12/2010, DJe, 8 fev. 2011.

BRASIL. Supremo Tribunal Federal. STF, ADI 217, relator: min. Ilmar Galvão, Tribunal Pleno, julgado em 28/08/2002, DJ, 13 set. 2002, PP-00062 Ement Vol-02082-01 PP-00001.

BRASIL. Supremo Tribunal Federal. MS 24631, relator min. Joaquim Barbosa, Tribunal Pleno, julgado em 9/8/2007.

BRASIL. Tribunal de Justiça do Estado de São Paulo. Apelação com revisão no 0096248 63.2002.8.26.0000 - 10 Câmara de Direito Público — rel. des. Antonio Carlos Villen — DJ, 10 jul. 2006.

BRASIL. 6a Vara Federal da Secção Judiciária de Itabaiana-SE. Ação Civil Pública no 000027415.2008.4.05.8501.

DECOMANI, Pedro Roberto. Improbidade administrativa. São Paulo: Dialética, 2007.

DRESCH DA SILVEIRA, Angélica M. A função consultiva da Advocacia-Geral da União na prevenção da corrupção nas licitações e contratações públicas. Revista Virtual da AGU, v. 9, n. 88, p. 1-24, maio 2009. Disponível em: <www.agu.gov.br/sistemas/site/Tem plateTexto.aspx?idConteudo $=83039 \&$ id_site $=111 \&$ ordenacao $=1>$. Acesso em: 17 out. 2013.

FAORO, Raymundo. Os donos do poder: formação do patronato político brasileiro. 5. ed. São Paulo: Globo, 2012.

FONSECA, Maurício. Rebelo: 'Nunca fui a um casamento em que a noiva chegasse na hora'. Ministro do Esporte diz que nenhum dos seis estádios ainda em obras será entregue em dezembro. O Globo. Disponível em: <http://oglobo.globo.com/esportes/copa-2014/rebelo-nunca-fui-um-casamento-emque-noiva-chegasse-na-hora-10967642\#ixzz2mk8uCI3L>. Acesso em: 6 dez. 2013.

MANCUSO, Rodolfo de C. Advocacia do setor público: riscos e obstáculos no limiar do novo milênio. Revista dos Tribunais, v. 92. n. 807, p. 27-55, jan. 2003.

MAZZILLI, Hugo N. A defesa dos Interesses difusos em juízo. 23. ed. São Paulo: Saraiva, 2010.

MEIRELLES, Hely L. Direito administrativo brasileiro. 29. ed. São Paulo: Malheiros, 2004.

MOREIRA NETO, Diogo de F. As funções essenciais à justiça e as procuraturas constitucionais. Revista de Informação Legislativa, v. 29, n. 116, p. 79-102, out./dez. 1992.

OSÓRIO, Fábio M. Observações sobre a improbidade dos agentes públicos à luz da Lei no 8.429/92. Revista dos Tribunais, São Paulo, v. 86, n. 740. p. 96-115, jun. 1997. 
PAZZAGLINI FILHO, Marino. Lei de Improbidade Administrativa comentada: aspectos constitucionais, administrativos, civis, criminais, processuais e de responsabilidade fiscal: legislação e jurisprudência atualizadas. 2. ed. São Paulo: Atlas, 2005.

PINHEIRO DE AMORIM, Gustavo Henrique. O advogado público na função consultiva, os pareceres jurídicos e a responsabilidade deles decorrente. In: MARINELA, Fernanda; BOLZAN, Fabrício (Coord.). Leituras complementares de direito administrativo: advocacia pública. Salvador: Juspodivm, 2008. p. 239-268.

VICENTIN, Adriana R. Advocacia pública e ação civil pública ambiental: Estado autor e Estado réu. In: BENJAMIN, Antônio H.; FIGUEIREDO, Guilherme J. P. de (Org.). Direito ambiental e as funções essenciais à justiça: o papel da advocacia de estado e da defensoria pública na proteção do meio ambiente. São Paulo: Revista dos Tribunais, 2011.

Marcelo Rodrigues Mazzei é mestrando em direitos coletivos e cidadania e especialista em processo civil pela Universidade de Ribeirão Preto (Unaerp) e procurador do município de Ribeirão Preto (SP). E-mail: mrmazzei@yahoo.com.br.

Marcelo Tarlá Lorenzi é mestrando em direitos coletivos e cidadania pela Universidade de Ribeirão Preto (Unaerp), especialista em direito tributário pela Universidade Anhanguera (Uniderp) e procurador do município de Ribeirão Preto (SP). E-mail: mtlorenzi@yahoo.com.

Henrique Parisi Pazeto é mestrando em direitos coletivos e cidadania e especialista em processo civil pela Universidade de Ribeirão Preto (Unaerp) e procurador do Município de Ribeirão Preto (SP). E-mail: rickpazeto@gmail.com.

Sebastião Sérgio da Silveira é doutor e mestre em direito pela Pontifícia Universidade Católica de São Paulo (PUC-SP), com pós-doutorado pela Universidade de Coimbra-Portugal. Professor titular e coordenador do Curso de Pós-Graduação em Direito da Universidade de Ribeirão Preto (Unaerp). Promotor de Justiça do Estado de São Paulo. E-mail: ssilveira@unaerp.br.

Zaiden Geraige Neto é doutor e mestre em direito pela Pontifícia Universidade Católica de São Paulo (PUC-SP). Professor titular do Curso de Pós-Graduação em Direito da Universidade de Ribeirão Preto (Unaerp). Advogado. E-mail: zgneto@uol.com.br. 